\title{
"Historians Should Explore Rather Than Sticking with What They Know": Interview with Professor Harold Cook, Brown University
}

\author{
TRISTAN MOSTERT and ANDREAS WEBER \\ E-mail: t.mostert@hum.leidenuniv.nl; a.weber@utwente.nl
}

Professor Harold Cook is a scholar of the history of science and medicine based at Brown University in Providence, Rhode Island. Readers of Itinerario probably know him best as the author of the monograph Matters of Exchange: Commerce, Medicine, and Science in the Dutch Golden Age, published in 2007. The book investigates, among other things, the global dimension of scientific and medical knowledge-production in the seventeenth century. His most recent study, on the early life of Descartes, was published only a couple of weeks before we conducted this interview. It shifts the focus back to the history of Europe, with travel central to Descartes' development. We met with Professor Cook on an unseasonably warm day in June at Museum Boerhaave, the Dutch national museum for the history of science and medicine in Leiden, where we discovered that his work had also been consulted in the context of the redesign of the museum's permanent exhibition about science and medicine in the Dutch Golden Age. We looked at some of the objects and books that were a source of inspiration when he wrote Matters of Exchange, and learned that part of his fascination for medicine in the Dutch Republic started in the museum library as he was leafing through the pamphlets about medicine kept there. But our conversation also brought us to the American Civil War, Mensheviks in Ann Arbor, Rhode Island traders in a painting from Surinam, and American accounting methods.

\section{Why and how did you decide to become a historian?}

When I was coming into my teenage years in the 1960s, there was an anniversary of the American Civil War, and my father gave me a birthday gift of a book on the war from 


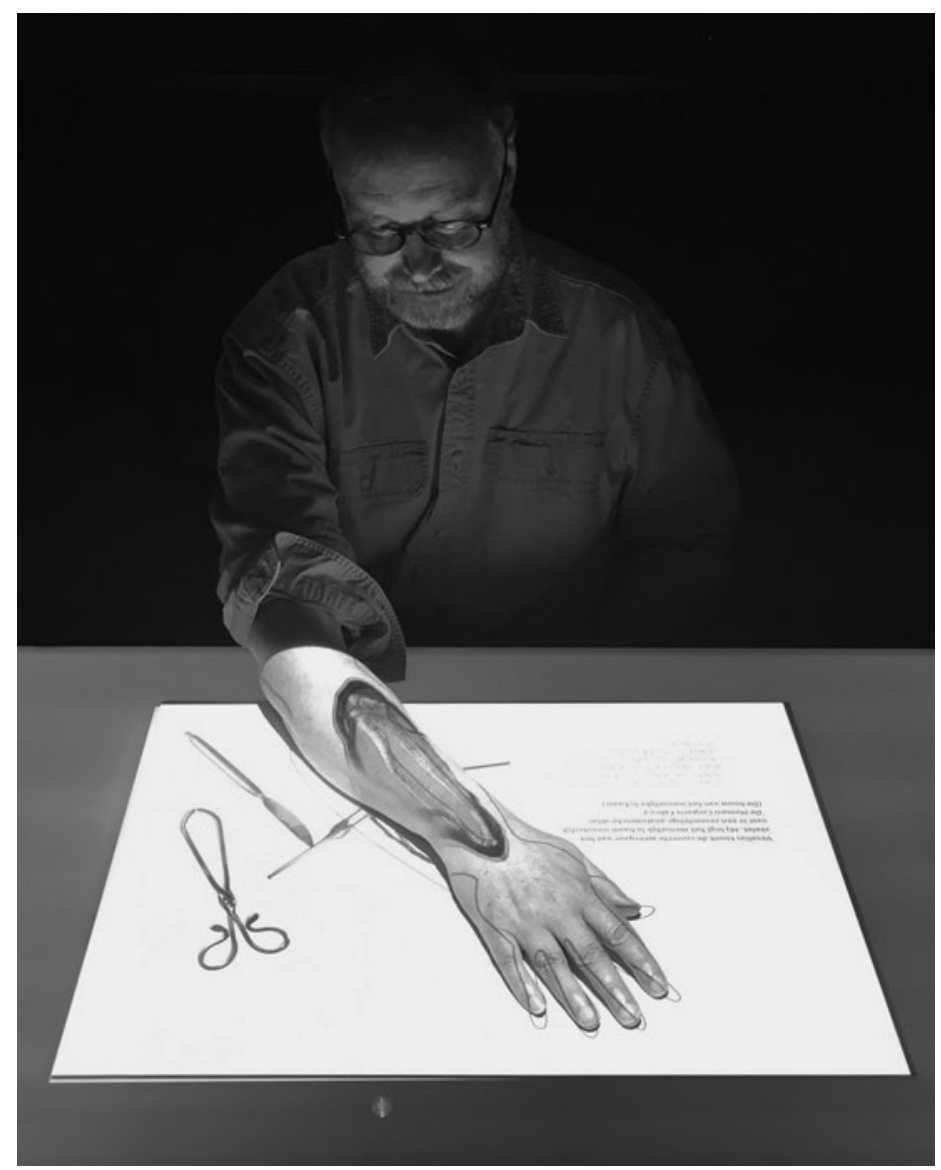

Figure 1. Prof. Cook at Rijksmuseum Boerhaave Leiden, summer 2018, picture by the authors.

American Heritage publishers (known for its popular history magazine). I found the book fascinating: maps, battles, and much political drama. Around that time we also made a family trip to see some relatives in Washington and my father dipped south a bit to see some of the battlefields, so I found that to be quite exciting.

I also really loved natural history - collecting butterflies and such. But when I was told that you couldn't be Charles Darwin anymore, that you had to specialize in some subject in biology, I thought I might continue to pursue history.

When I went into college I chose a school known for having a good history professor, Eric Kollman. It was Cornell College - a little liberal arts college in Mount Vernon, Iowa, with some eight hundred students. I took two of this professor's courses and I really loved them. I eventually dedicated my first book to him. He was originally from Vienna and had been a member of the Vienna Circle between the wars and a teacher of history at the 
gymnasium. But he was Jewish and after the Anschluss he was able to escape with his wife, because one of the SS guards had been a student of his. (The rest of his family was killed in the Holocaust.) He then managed to come to the United States, without knowing any English, and he started teaching at Cornell College, learning English from the Oxford English Dictionary. He knew the names of all the popes and everything else, he knew the history of the English language in a way I didn't at all. So I just thought he was fabulous.

\section{Did this professor also arouse your interest in medical history?}

No, he specialized in the history of Austria and taught about Europe. But I also had a course in the philosophy of science and I thought that was an interesting subject. After I went to college I decided to do a $\mathrm{PhD}$, if I was admitted to any decent graduate school. I was accepted at two universities, and chose the University of Michigan. I had had some Russian in high school and college, and I actually went there to study nineteenth-century Russian history. My first seminar paper was on the Murid movement in the Caucasus, which was the Islamic revivalist movement that Pushkin, Lermontov, Tolstoy, and many others encountered during their military services.

This was during the Vietnam War, and I could see some parallels that were interesting to me. But I also took a course about the scientific revolution, and that really captured my attention. My first class presentation was on Robert K. Merton's Science and the Economy of Seventeenth-Century England (1939), and its themes continued to motivate my interests. So I decided to switch fields - I was only at the end of my first year so I could still do that. But there was only one historian of science in the history department, Nicholas H. Steneck. Although he studied medieval science, he was a very good supervisor, because he knew the field in general and could ask very good questions, but let us do our own research into whatever interested us. After I finished my doctorate I was facing unemployment, but then a one-year job came along, and then from that another short-term job, and somehow I was lucky enough to continue.

\section{Your PhD was about medical history in seventeenth-century England. Could you elaborate on how you came to be interested in this topic?}

At the time, the history department in Ann Arbor had very good connections with members of the Annales school in Paris. The department was strong in early modern French history, and everybody at that time was also talking about Foucault; a couple of his books had recently been translated, including Birth of the Clinic, so I did a seminar paper inspired by it. The same period also saw the growth of women's history, as it was called at that time, and the emergence of interesting stories of how women had been excluded from different professions, including medicine, and how the male body had been taken to be the 'normal' human body, giving the study of women's diseases a counter-cultural edge. I started to realize that medicine was really interesting for a historian. It contains 
everything I find fascinating - politics, economy, gender and society, culture, religion, science, you name it, you can find it there. I realized it would be a good lens through which to study the interaction between different fields of historical discourse. So I did some looking around and found a literature on the history of medicine in London and I thought I could make some contributions there.

\section{Foucault's books were translated into English at the time of the Vietnam War, which triggered intensive debates at campuses in the United States. To what extent was the history of science a politicized field? And were you active in a student movement?}

I was not directly politically active. I followed what was going on. I worked in factories in the summers with people who had come from Appalachia and Puerto Rico, had friends who had been caught up in the police riot in Chicago during the Democratic Convention of 1968, followed news about the civil rights movement, and kept up with the details of the Watergate investigation; and of course I listened to the music of the time, from Mozart and Bach to jazz, blues, and politicized rock and roll. I signed petitions and attended meetings, but I was no activist. I began reading the New York Review of Books, where they reviewed a lot of New Left books. And of course many professors at Ann Arbor were politically aware, if not engaged; there was a fight going on in the history department between the conservative old guard and a group I once heard describe themselves as "Mensheviks."1 They were advocating reform. And many of them wanted to bring in people to study labour history, women's history, and to broaden some of the geographical scope of the department. It was a great time to be a graduate student; you would have courses where people with different political as well as historical views were trying to think out the grounding of their arguments through their activity in the department—so it was an excellent training!

\section{Was there a question that you yourself might be drafted to go to Vietnam?}

Yes there was, and I still have somewhere in a folder at home my draft card - I never burnt it, so I still have it. I had what was called a 2-S deferment to go to college. One of my friends went to a different university. He smoked too much dope and drank too much beer, and he didn't keep his grade average high enough (you needed a B or better). So he slipped one semester, and was drafted and sent to Vietnam. He had a terrible time there, warning me in a letter to stay away from it if I could. Fortunately my grades were good enough to keep the deferment. And then just about the time I graduated from college, there was another presidential election and Nixon and Kissinger ended the draft to help them win the election. So by the time I graduated I was safe. And I also had long hair at the time and I smoked a lot of dope myself. I didn't think of myself as a leftist, but I was very much caught up in the moment, and it changed me a lot. 
One other thing about politics. There was a scholar named Michael Taussig who did medical anthropology, and I listened to some of his lectures in Ann Arbor and I asked him to be on my dissertation committee. In the end, he wasn't able to join because he was on field research when I defended my dissertation. He was particularly Marxist in his interpretation. He was working on a book that became his study of witchcraft in which he studied the effects of capitalism in Latin America (Columbia and Bolivia). The monograph has a very Marxist title. ${ }^{2}$ Taussig argued that the arrival of capital threatened sustainable forms of agriculture in villages. If someone could get a tractor, he would be able to make more profit. This eventually changed the village economy, some people would begin to profit and would buy out their neighbours who had to work for them, leading to a witch craze, because the villagers wouldn't understand what was happening to them. They only felt something evil was going on. That also affected me. And I had a friend who since then has become very conservative in his study of the economy, because some of us were talking about the relationship between, to put it very generally, knowledge and economy, and how those were working together or against each other. Those conversations were important back then. The book resulting from my dissertation argued that the growing medical marketplace had powerful effects on the history of medical ideas and practices, and by implication on the so-called scientific revolution. ${ }^{3}$

\section{Yet, your first academic publication was remarkably global: a broad assessment of the impact of the discovery of the New World on the sixteenth-century worldview - in a journal about the voyages of discovery! Would it be fair to say that the global approach to the history of science you would later lay out in Matters of Exchange had your interest from the very beginning?}

That paper came from a seminar with Charles Boxer. After he retired from King's College, he spent a semester in Ann Arbor, teaching a seminar that was being run through the Clements Library, which has a very good collection of books, maps, and other materials on the early Americas. I had always had an interest in what were then called voyages of exploration, so I took that seminar, and that got me writing things along these lines. Because of that, one of the fields I specialized in during my early $\mathrm{PhD}$ period was early European expansion, taught by Charles Gibson, who became well known for his work on Aztecs and Spanish colonial rule. ${ }^{4}$ So that was also something in my background that came out later again, for instance in Matters of Exchange. But at the time, it was just a side interest. The history department in Ann Arbor was very large, and we were encouraged to study widely, in terms of sitting in on people's courses, so I did that: I sat in on a course on Ottoman history and other such things. I was trying to become a historian with a wide orientation, because I thought that I would teach at a little liberal arts college and I might have to offer courses on a variety of themes; so I really wanted a general education as a historian. 
In the preface of Matters of Exchange, you write that you became interested in Dutch history because you ran into some Dutchmen in Stuart England during your PhD research, and had learned that if you want to change topics, you should do it soon after finishing your PhD. Still, what hooked you about this subject so much that you decided to master an entirely new topic and language for it?

At the time, there was some comparative history going on at Ann Arbor and the Journal of Comparative History was published from there. At the end of my first book, I had a few points of comparison I looked at to decide how much of what I had found might be connected only to England or France, or how much might be part of a general movement called the scientific revolution in Europe. First I was thinking about adding France to the equation, because I knew French history a little bit and I could read the language. But I had come across documents in Dutch, and it began to dawn on me that there was this Anglo-Dutch connection. And as I was considering that that might be a really interesting point of comparison, I encountered three Dutch medical historians at a conference: Antonie Luyendijk-Elshout, Harm Beukers, and Mart van Lieburg. ${ }^{5}$ They were presenting at this conference in Cambridge, and over dinner I told them I' $d$ be really interested in learning more about the medical history of their country at some point, as that would be an interesting point of comparison for me, and they answered: "Well, if you ever come, let us know." So in 1987, when I had a sabbatical at the University of Wisconsin, I wrote to them, and Antonie Luyendijk-Elshout replied that she could probably arrange some office space for me. Harm Beukers, who was her successor as she was on her way towards retirement at the time, very kindly let me use a desk and chair in his office in the medical school. He became a mentor for me, and through him I also met people like Toon Kerkhof who was a student of Daniël de Moulin from the medical history programme at the University of Nijmegen.

\section{What was your first big case study in the new field?}

While I was thinking about learning Dutch history and Dutch history of medicine, I took a job at the University of Wisconsin-Madison. There they had a couple of young people in the German department who gave elementary courses in Dutch, so I sat in on a Dutch course with undergraduates who were far better with the language than I was (it was very humbling), and then I took up this invitation to come to Leiden and continued my study of the language here. I had a project on Joannes Groenevelt, the seventeenth-century medic who ended up working in England. During my stay in the Netherlands I used the study of him as a way to learn Dutch handwriting of the period and learn how the archives worked here. I started finding out so much, and so many clues about him and his friends in Deventer, that I felt that it could become more than an article, and it eventually grew into a book. ${ }^{6}$ 


\section{What made Joannes Groenevelt so special for you?}

I found many of Groenevelt's papers in the Sloane collection in London, and I found other papers of his and his friends in Deventer, Amsterdam, and other places. My original idea was that the Dutch Republic would be a place where I might explore some of the connections between what I would now call material culture and the scientific revolution. I felt the way in might be through art history, and there was a very rich literature on the artists here, how they made pigments, and the nature of "realism" or "naturalism" in their work. Svetlana Alpers had recently published her book on Dutch art that made the case for empiricism, and I was making a case for empiricism in medicine, arguing that because the medics were well connected to the "scientists" (sorry for the anachronism), empiricism was important for the scientific revolution; that it was not just a change in culture and theory, and that one could see this by looking at the medical community. I had also been encouraged by Simon Schama, who was then finishing his Embarrassment of Riches. ${ }^{7}$ I hoped the Dutch sources would give me some further examples of how that worked. I came to the Netherlands with this mind-set, but then it gradually became science and capitalism, whereas I started from empiricism and material culture. So that was a tangent on the way to Matters of Exchange.

\section{At a certain point you left the University of Wisconsin in Madison and moved to London as director of the Wellcome Trust Centre. How did that influence your work?}

I went to London in 2000, and Matters of Exchange was published in 2007, so the manuscript was completed somewhere around 2005 or 2006 . I worked on it very hard while in London, mostly in the evenings, weekends, and holidays, as I felt I really needed to finish that book. In Madison, the history of science department was not very welcoming to the kind of social history of medicine approach I cared about. I always felt like I was being fought by the old guard, which made me think more about trying to create some elbow room for PhD students in Wisconsin, to expand the scope of the field and help bring the department into the mainstream of where I saw the history of science going. The classic approach was what people like Floris Cohen call the grand tradition of the history of science, with authors like Alexandre Koyré putting forward the notion that a few smart people, sometimes called geniuses, made the transition to modern science. The pushback against that was what we could call cultural construction, which came from Steven Shapin, Simon Schaffer, Lorraine Daston, and many others. ${ }^{8}$ I thought that cultural construction was just another way of studying the history of ideas of small elite groups in society-so the social history of medicine approach was essentially different, seeing the so-called scientific revolution as an emergent phenomenon. Cultural construction felt a little bit stultified, and I felt that the "empirics" and other non-elite figures needed to be brought into the story: that was my original agenda.

When I arrived in London, many of my colleagues remained oriented towards the work of Michel Foucault. I was brought up with Foucault, but, as fascinating and 
powerful as his vision was, it was a little too domineering. It was a monotheism of culture. Roy Porter was pushing back against that in all kinds of ways, but mostly with the history of madness, showing that in England all kinds of small medical entrepreneurs set up houses to take care of mad people and made their money that way, as opposed to the large institutions in France. So that was a different story of the history of medicine, at least in England, giving an alternative to Foucault's ideas. In particular Porter's interest in commerce, and how people got interested in commerce partly because of pleasure and passions, and not just because of a system of domination, was of great interest to me-his work and mine shared several themes. I felt I could pursue that line of thinking more freely at the Wellcome Centre than in Madison.

\section{Of course your most monumental book, for Itinerario readers, is Matters of Exchange. Could you tell us a little bit about the challenges you wrestled with when writing it?}

One of the things I needed to do was to read as much as I could on what is often called the Dutch Golden Age. I read lots of things outside the history of medicine, and spent a lot of time here in the wonderful Boerhaave Museum library, leafing through all these seventeenth-century pamphlets. I learned about so many interesting figures I had not known about, as most of the literature about them was in Dutch. Only Boerhaave was commonly known outside the Netherlands, and Huygens. Otherwise, English-language historians did not know very much about the Dutch Republic. Jonathan Israel was starting to write about it, bringing more attention to it, and Dutch authors were starting to write in English, but it was still very early in that process. So I read as much as I could to just familiarize myself with the period. I met Karel Davids in passing, and talked about his research in navigation, which also connected to the history of capitalism. Davids's work was inspirational for me in terms of how he included the history of the Dutch East India Company in his narrative. ${ }^{9}$ And my mentor Harm Beukers was beginning to study Japanese to look at the DutchJapanese connections (mostly for the eighteenth and nineteenth century), and it occurred to me that I couldn't understand the experience of the Dutch here without understanding where they were in the world. So I also began to read about the East and West India Companies.

\section{When did the idea to link empiricism and commerce emerge?}

In the beginning, my view that empiricism was important in the science and medicine of the period seemed to fall into place very well and early in the project on the Netherlands. But as I began to learn more and more about the Dutch seventeenth century, it turned many of my assumptions on their head. I'd been brought up partly on the Protestantism and science argument, but here some of the great dominees also hated Copernicanism, and it occurred to me that the story was similar but different enough 
to be surprising. It challenged many of my assumptions, some of which had to do with politics, as some of the stories I knew and had written about had to do with scientific patronage. But when I think of patrons of the period I think of princes and those sorts of people. The House of Orange didn't seem to be particularly active in this area, nothing unusual, let's say. And yet, many important developments were happening, at universities but also outside them, so there was something about the Dutch urban environment that started to interest me. That led to: how did politics happen here, and of course this connects to commerce and taxation and war-making. So I began to have a much better sense of the structures of power that included knowledge and scientific and medical empiricism. That ended up becoming the theme throughout the book. I don't know if it would have happened if I had stayed in Wisconsin, because even though the Berlin Wall had come down, the American system was so dominated by anti-communism that this would still seem a bit Marxist in America, and I don't know whether I would have had the courage there to write it in the way I did, but in Britain it didn't seem to be a problem for me.

\section{Which advice would you give historians who are interested in contributing to a global history of knowledge?}

Well, the puzzle for me at the moment might be put in terms of the commensurable and incommensurable aspects of globalization, or world economies. There is a whole range of things that we lump together under the word knowledge. When I come across words about knowledge in other languages I pay attention because there are often different kinds of connotations, and there is a range of assumptions and subjects that go into this thing called knowledge. Some of these might be considered to be related to language, upbringing, cultural identity, and so on, and those are, I think, kinds of knowledge that are "sticky," that you grow up with, you hold fast to, that are really important and often difficult for other people to understand. But other parts of knowledge are shared-sometimes more, sometimes less, but as much as we have paid attention in the history of science to incommensurability, some things are commensurable too. And that's where my old interest in empiricism and economy comes into it. So this question of what's shared and not shared and how they work together or against one another ... there are frictions, and how these frictions can produce interesting historical events is important. The Latin word translatio (to move in place or status, as well as language) is a helpful tool. I've also read much more about colonial history over the years, and very clearly knowledge is a very important part of any colonial system, but so is power-sometimes the power of coercion, sometimes power in other forms. I was beginning to recognize that when I wrote Matters of Exchange. On the one hand, there were people like Bontius, the doctor working in the East Indies in the early seventeenth century I write about in Matters of Exchange, who seemed to appreciate the knowledge he was gathering from local people, recognizing they were not barbarian, so he made a case for respecting them and their knowledge. On the other hand, in just these same years, there was the extermination of the people 
on the Banda Islands. I am unsure how to reconcile these two things with one another. For the book I just left it juxtaposed, because I didn't know how to connect it. I am still puzzled about how to handle those, let's say, conflicts of the colonial system (and their implications for the histories of the home countries).

\section{Your writing, while supposedly for a specialist audience, is often very accessible, vivid, and literary. Do you have people who inspire you in terms of writing style?}

Well that's very kind of you. I don't have any particular model but have always cared about writing accessibly, and whatever I write, whether it's a short article or a book, goes through many, many drafts. I'm always trying to see if I can say something more clearly or simply, or reorganize my thoughts to make them more apparent. I don't think of myself as very quick in my understanding of things, but I work at them, and I work at my writing.

When very young I became an eager reader of Tolkien's Lord of the Rings, and in more recent years I would name Cees Nooteboom and Amitav Ghosh as especially inspirational authors. Recently I've given more attention to metaphor as a way of expressing things. Some of that comes from Michel Serres, ${ }^{10}$ who keeps bringing up mythology in his writing, which I think works really well for making a short case about human relations with worldly powers. He uses myths as metaphors, which, although dangerous if you're not careful with them, might work well in some cases. I tried to work out a few for my new book about Descartes that could recur throughout the text but would sustain a view of his early life. Serres has a sense of the whole person that's brought out in mythology, and how he grounds big ideas in bodily experiences is an example I think about a lot.

\section{About your new book about the young Descartes. It seems that almost every time you finish a book, you use it as a springboard into an entirely new field. Is this a deliberate thing you do?}

Well, I do think one thing leads to another, and as a grad student I was encouraged to think about history as something historians should explore rather than always sticking with what they know. One of the joys of working at Brown University is that the students are very good, but there are no set requirements. The students can study what they want and we, as faculty, can teach what we want. This is very freeing for everyone-I don't have to identify myself as a particular kind of historian: I can study, write, and teach whatever interests me. So I have this privilege of being able to move on if I want to.

Writing about Descartes was intimidating, but Descartes is also not entirely new to me. There was a standard story of Descartes that I grew up with, which was a way of fending off empiricism, cultural construction, and so on,- - a story about how great thinkers, writing by themselves in a corner, could change the world. For me, the accepted version of Descartes was one of those problem cases, and when I was studying medicine in England I could sort 
of ignore him, because of the English turn against Cartesianism (although they were all reading him). But studying the Netherlands I no longer could: not only did Descartes live here, but he was very important in the scientific and medical discourse in the Netherlands. One of the referees for Matters of Exchange commented, "What's Descartes doing here, there's a whole chapter on him." But I did think he needed to be there.

I thought about him for a long time. And one of the people who became important for me in thinking about the Netherlands and the implications of physiology in the seventeenth century was Bernard Mandeville, who is important for political economy in the English-speaking world: I think his views are rooted in the Dutch Republic's political economy, but he was also trained in Cartesian physiology. So this Cartesian business bothered me for a long time, and I thought that rather than go after it directly by writing about Descartes' philosophy or physiology or something like that, I would try to see better who he was and what the problems were that he was trying to address. The book ends before he writes philosophy-he became an exile in the Republic, where he began to publish - but I thought I should at least try to make him into a human being to see how he navigated his world; that would solve some problems for me.

\section{The book is really just out, so that there are as yet very few reviews. Any word from France yet?}

No, I'm very nervous. I've only seen a review in the Literary Review from Britain, by Dmitri Levitin from All Soul's college, Oxford. He just doesn't believe it. Too many "probablies." I accept that criticism, but he also doesn't believe, for instance, Descartes could have been at the Siege of La Rochelle. And I do, I think the evidence points in that direction. His conclusion is that I'm postmodern. I'm not sure what that means for him. It seems to me that he thinks I'm trying to make Descartes into a political animal, whereas I think he was a marginal young nobleman living in a dangerous time. Anyway, I will be very interested to see how this will turn out, and whether I will need to defend myself with a sword at any point.

\section{You're here as part of a NIAS project called Borders and the Transfer of Knowledge. What is that project about?}

It's the last of four projects that were organized with NIAS [Netherlands Institute for Advanced Study] by the Descartes Centre in Utrecht. We've had some debates by email, and now in person, about whether the subject might change into something like "Regulating knowledge in an entangled world," trying to figure out these questions of, let's say, commensurability, and how things move in a world of entangled relationships.

The idea is to publish a collective volume from this. I arrived with a study fitting within the project, which I'm now scrambling to get ready for print-it's about Cornelis de Bruyn, the artist who travelled around the world and published with the support of Nicolaes Witsen, and he allows me to think again about the regenten and what 


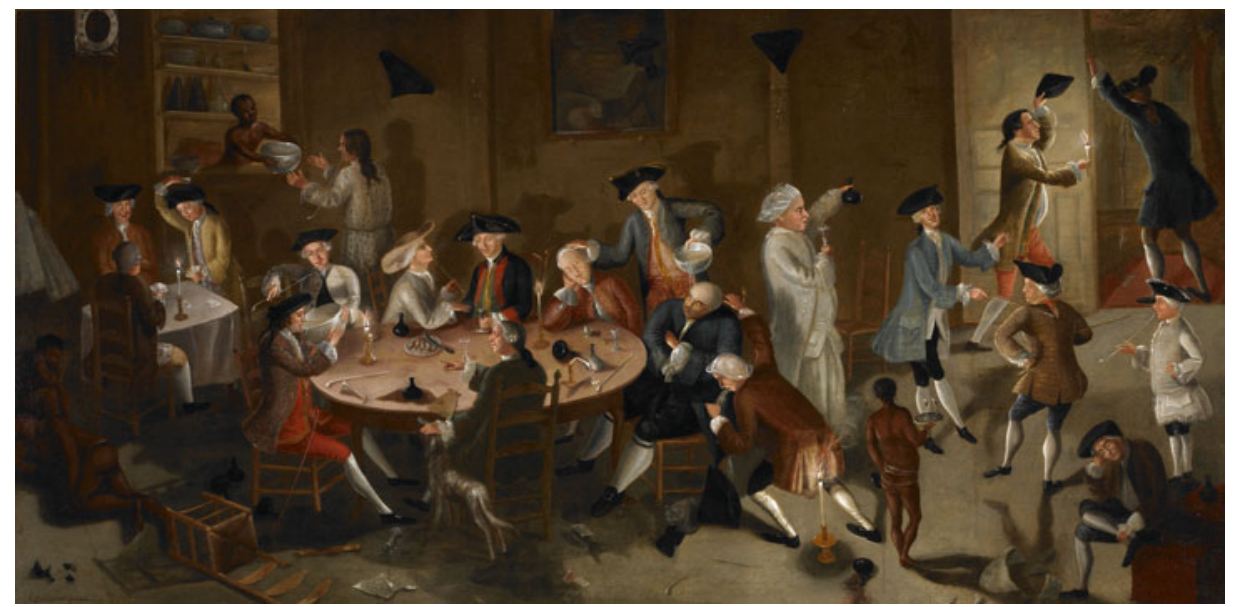

Figure 2. John Greenwood, American, 1727-1792; Sea Captains Carousing in Surinam, c.1752-58; oil on bed ticking; 37 3/4 × 75 inches; Saint Louis Art Museum, Museum Purchase 256:1948.

they cared about in terms of knowledge. And the visit here gives me the opportunity to look at the original materials themselves.

Final question: what entirely new subject will you jump to next?

I'm not sure yet, although I have some ideas. I continue to write on early modern commerce and science, and the global movements of some aspects of medicine. But one of the things that has attracted my interest more and more, living in Rhode Island, are the Dutch connections in early America, because Rhode Island merchants were trying to avoid English taxes by going to Surinam and Curacao, so smuggling was an important part of the Rhode Island economy at the time, and the Dutch supply of molasses was very important to them. There is a famous painting of eighteenth-century Dutch merchants from Rhode Island, in a sort of Jan Steen style, having a big party with drunkenness and people puking and all that, but although all the white faces are merchants from Rhode Island, the painting was done in Surinam.

Also, there is a wonderful whaling museum in New Bedford, Massachusetts, which was the centre of the whaling industry, and at one of the antique dealers who exhibited there recently I had a look at a map of New Holland, probably from a Blaeu Atlas. It was very expensive and I didn't buy it, but it showed all the Dutch names for Cape Cod and the entire area. When I think of New Holland I think of New Amsterdam and the Hudson River, but I had never really considered how active the WIC was in this much wider area. Perhaps there is still a bit more to say about why American accounting methods are still Dutch. 


\section{Notes}

1 The Mensheviks were a moderate fraction of the Russian socialist movement in the early twentieth century.

2 Michael Taussig, The Devil and Commodity Fetishism in South America. Chapel Hill: University of North Carolina Press, 1980.

3 The Decline of the Old Medical Regime in Stuart London (Ithaca, N.Y.: Cornell University Press, 1986); on that phrase, see the introduction to Mark S. R. Jenner and Patrick Wallis, eds. Medicine and the Market in England and Its Colonies, c. 1450-c. 1850. Houndmills, Basingstoke: Palgrave Macmillan, 2007.

4 Charles Gibson, The Aztecs Under Spanish Rule: A History of the Indians of the Valley of Mexico, 1519-1810. Stanford, Calif.: Stanford University Press, 1964.

5 Prof. Dr. Antonie Luyendijk-Elshout was professor by special appointment of the history of medicine at Leiden University, and, among other things, was actively involved in the development of the Boerhaave Museum. Harm Beukers succeeded her in that role in 1987. Mart van Lieburg was professor of the history of medicine at various institutions.

6 Cook, Harold John. Trials of an Ordinary Doctor: Joannes Groenevelt in Seventeenth-Century London. Baltimore: Johns Hopkins University Press, 1994.

7 Alpers, Svetlana. The Art of Describing: Dutch Art in the Seventeenth Century. Chicago: University of Chicago Press, 1983; Simon Schama. The Embarrassment of Riches: An Interpretation of Dutch Culture in the Golden Age. London: Collins, 1987.

8 E.g. Steven Shapin and Simon Schaffer, Leviathan and the Air-Pump. Princeton, N.J.: Princeton University Press, 1985.

9 Karel Davids, The Rise and Decline of Dutch Technological Leadership: Technology, Economy and Culture in the Netherlands, 1350-1800 2 vols. Leiden: Brill 2008.

10 Michel Serres is a French philosopher who has written extensively about science and its history. 